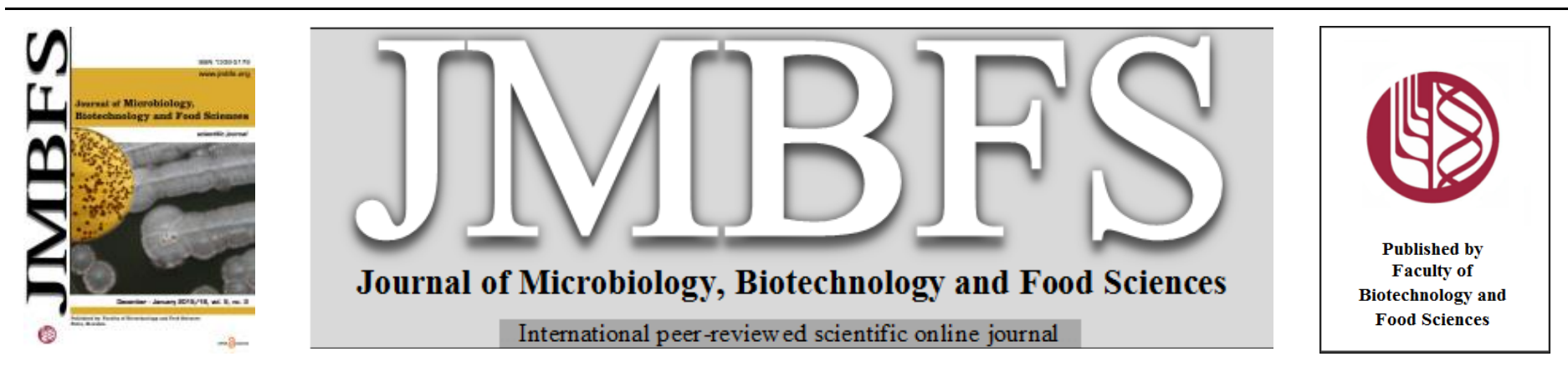

\title{
ANTOXIDANT ACTIVITY AND PHENOLICS COMPOSITION IN STEVIA REBAUDIANA PLANTS OF DIFFERENT ORGIN
}

Oksana Sytar ${ }^{1,3}$, Asel Borankulova ${ }^{4}$, Yaroslav Shevchenko ${ }^{1}$, Alexandra Wendt ${ }^{1}$ and Iryna Smetanska ${ }^{1,2}$

Address(es):

${ }^{1}$ Department of Methods of Food Biotechnology, Institute of Food Technology and Food Chemistry, Berlin University of Technology, Königin-Luise-Straße 22, 14195 Berlin.

${ }^{2}$ Department of Plant Food Processing, Agricultural Faculty, University of Applied Science Weihenstephan-Triesdorf, Steingruber Str. 2, 91746 Weidenbach, Germany.

${ }^{3}$ Taras Shevchenko National University of Kyiv, Department of Plant Physiology and Ecology, Institute of Biology, 64, Volodymyrs'ka St., 01601 Kyiv, Ukraine. ${ }^{4}$ Department of Technology of Food Products, Processing Industries and Biotechnology, Taraz State University named after MK Dulati, Suleimen Str., 7, Taraz 080012, Republic of Kazakhstan.

*Corresponding author: oksana.sytar@gmail.com

doi: $10.15414 /$ jmbfs.2015/16.5.3.221-224

\section{ARTICLE INFO}

Received 18. 5. 2015

Revised 3. 9. 2015

Accepted 9. 9. 2015

Published 1. 12. 2015

Regular article open $\partial_{\text {AcCESS }}$

\section{ABSTRACT}

The antioxidant activity and total phenolic contents in leaves and leaf extracts of Stevia plants grown under the different conditions of Egypt, India, Paraguay, Greece and Spain were studied. The moderate levels of total phenolics (from 5.64 to $6.45 \mathrm{mg} \mathrm{mL}^{-1}$ ) was found in Stevia leaf extracts from Egypt, India and Greece which can depend from the climate conditions during growing season of Stevia plants. High amounts of total phenolics contained leaves of Stevia plants from Paraguay and Spain (from 8.69 to $9.44 \mathrm{mg} \mathrm{mL}^{-1}$ ). The antioxidant activity in Stevia plants from Paraguay was about $46 \%$ and from Spain about 57\%. The individual profile of phenolic acids differed between samples, Stevia leaf extracts from Greece, Spain and Paraguay has been shown the high contents of caffeic acid (29.9, $22.1^{3}$ and $16.2 \mu \mathrm{M} \mathrm{mL}^{-1}$ respectively) and catechin $\left(52.9,64.2\right.$ and $\left.48.1 \mu \mathrm{M} \mathrm{mL}^{-1}\right)$ as compared to samples from Egypt and India. In these variants were present the high content of steviolbioside and RT 21 too. In same time another redistribution quantity of identified phenolics compounds in their composition compared with all experimental samples has been presented in the Stevia leaves from Greece. In leaf extract from Greece quantity of steviolbioside was less on 50\% compared with variants of leaf extracts from India and Spain.

Keywords: Stevia rebaudiana; antioxidant activity; phenolics, phenolic acids

\section{INTRODUCTION}

Antioxidants are compounds that inhibit or delay the oxidation of other molecules by inhibiting the initiation or propagation of oxidizing chain reactions. Today the interest in natural antioxidants has increased considerably (Velioglu $\boldsymbol{e t}$ al.,1998). In the literature of last few years has been demonstrated that phenolic compounds are strong natural antioxidant (Mohdaly et al.,2010).

Phenolic compounds are divided into several different groups, distinguished by the number of constitutive carbon atoms in conjunction with the structure of the basic phenolic skeleton as phenols, benzoic acids, phenylopropanoids and flavonoids (Chaudiere et al.,1999). They have been reported to possess antioxidant activity which allows them to scavenge both active oxygen species and electrophyles, to inhibit nitrosation and to chelate metal ions, to have the potential for autoxidation and the capability to modulate certain cellular enzyme activities (Rice-Evans et al.,1995). Antioxidant and radical scavenging activities correlate with total phenolic contents (Zhang and Hamauzu, 2004) and now many investigations of various food plants concentrated on these parameters.

$S$. rebundiana is a natural sweet herb native of North-Eastern Paraguay, cultivated as a cash crops in number of countries. This culture still cultivated today in Paraguay, Mexico, Central America, Japan, China, Malaysia, India and South Korea. In Europe it is reported to be cultivated in Spain, Belgium, France and the UK. The ability of phenolic compounds to act as antioxidants has been demonstrated in the research with Stevia plants. The results obtained in this study clearly indicate that $S$. rebaudiana has a significant potential to use as a natural antioxidant agent (Shukla et al.,2009). Leaf extract of $S$. rebaudiana promotes effects on certain physiological systems such as the cardiovascular and renal and influences hypertension and hyperglycemia. The bioactive compounds of Stevia leaf extracts are safe to use and also having antimicrobial, antibacterial, antiviral and anti-yeast activity (Goyal, $\boldsymbol{e t}$ al.,2010). These activities may be correlated with the presence of antioxidant compounds (Tadhani, et al.,2007). More recently, purified extracts of $S$. rebaudiana (Bertoni) Bertoni (Compositae) containing the sweet ent-kaurane-type diterpene glycosides stevioside and rebaudioside A have become popular as "dietary supplements" (Prakash $\boldsymbol{e t}$ al.,2014). Sweetness of $1.0 \mathrm{~g}$ of dry stevia leaves in $100 \mathrm{ml}$ water was equivalent to a sucrose solution containing $20 \mathrm{~g}$ of sucrose (Mishra et al.,2010). The antioxidant activity of the extracts of Stevia was synergistic when it was mixed with coffee and limejuice. Complete purification of Stevia leaf extracts to obtain pure glycosides is not necessary for it to become a commercially acceptable sweetener (Kaushik et al.,2010). With aim to keep antioxidant activity of extracts of Stevia it has been proposed to retain the polyphenols and remove chlorophylls in the purification processes of Stevia extracts.

The aim of this research was to screen a large number of Stevia plants material extracts of different origin with respect of their total phenolic content and antioxidant activity in order to find the best sources of natural antioxidants.

\section{MATERIALS AND METHODS}

\section{Plant Material}

Leaves of Stevia plants (Stevia rebaudiana) from Egypt, India, Paraguay, Greece and Spain (Andalucía) were assayed for antioxidant activity and phenolic content. The samples were kindly presented by European Stevia Association (EUSTAS). According to data sources compiled by the World Meteorological Organization (WMO) the decade of the 2000s (2000'2009) was warmer than the decade spanning the 1990s (1990-1999). In the Table 1 is presented climatic conditions during growing season of Stevia plants. 
Table 1 The climatic conditions during growing season of Stevia plants

\begin{tabular}{lcc}
\hline Country & Average temperature, ${ }^{\circ} \mathbf{C}$ & Humidity, $\mathbf{~ m m} / \mathbf{y e a r}$ \\
\hline Egypt & 28.5 & $40-60$ \\
\hline India (tropical dry) & 38 & $400-750$ \\
\hline Paraguay & 34 & 1270 \\
\hline Greece & 37 & 800 \\
\hline Spain & 29 & 250
\end{tabular}

Especially temperatures were more than $+3^{\circ} \mathrm{C}$ above average in large parts of Paraguay, south-east Bolivia and southern Brazil, making it the warmest conditions in the past 50 years for many locations.

\section{Determination of Antioxidant Activity}

The method of Kedare and Singh has been used for the determination of antioxidant activity of different Stevia plants cultivated under the different climatic conditions (Kedare and Singh, 2011).

The initial weight of every Stevia dry leaves sample was $0.02 \mathrm{~g}$. All samples were assayed in six times. For the extraction $0,02 \mathrm{~g}$ of dry material were placed in eppendorf tubes and they were fill up with $1 \mathrm{ml}$ of distilled water and heated 15 min under $95{ }^{\circ} \mathrm{C}$. Then the material was centrifugated for 5 minutes $(12000$ $\left.\mathrm{rpm}, 25^{\circ} \mathrm{C}\right)$. The extract was replaced in a new tube. The supernatant was filled up again with $1 \mathrm{ml}$ of distilled water and reheated for 10 minutes under $95{ }^{\circ} \mathrm{C}$, then spinned again $\left(12000 \mathrm{rpm}, 25{ }^{\circ} \mathrm{C}, 5 \mathrm{~min}\right)$. The extract was filled into the new tube.

As stock reagent solution we used $10^{-3}$ mol.. $\mathrm{L}^{-1}$ 2,2-diphenyl-1-picrylhydrazyl (DPPH). The solution for the extraction was obtained by mixing $6 \mathrm{ml}$ of the stock solution with $100 \mathrm{ml}$ methanol. All samples were measured at $515 \mathrm{~nm}$ on a spectrophotometer (Jenway $6505 \mathrm{UV} / \mathrm{Vis}$ Spectrophotometer), the time between the sample preparation and measurements was $30 \mathrm{~min}$.

The absorbance was plotted against time, as a kinetic curve, and the absolute value of slope was expressed as antioxidant value (AOX). Antioxidant activity (AA) was also calculated as percent inhibition relative to control using the following equation (Al-Saikhan et al.,1995). A control sample with no added extract was also analyzed and the scavenging percentage was calculated according to the following equation:

DPPH scavenging capacity $(\%)=[(\mathrm{A}$ control $-\mathrm{A}$ sample $) / \mathrm{A}$ control $] * 100$

\section{Determination of total phenolics}

Total phenolics were determined by using Folin-Ciocalteu reagent (Singleton and Rossi, 1965). $20 \mathrm{mg}$ of sample was extracted for $10 \mathrm{~min}$ with $0.5 \mathrm{~mL}$ of $70 \%$ methanol at the temperature $70{ }^{\circ} \mathrm{C}$. The mixture was centrifuged at $3500 \mathrm{rpm}$ for $10 \mathrm{~min}$ and the supernatant decanted into $2 \mathrm{~mL}$ vials. The pellets were reextracted under identical conditions. Supernatants were combined and used for total phenolics assay. $20 \mu \mathrm{L}$ of extract was dissolved into $2 \mathrm{~mL}$ of distilled water. $200 \mu \mathrm{L}$ of dissolved extract was mixed with $1 \mathrm{~mL}$ of Folin-Ciocalteu reagent (previously diluted 10 -fold with distilled water) and kept at $25{ }^{\circ} \mathrm{C}$ for $3-8 \mathrm{~min}$ $0.8 \mathrm{~mL}$ of sodium bicarbonate $(75 \mathrm{~g} / \mathrm{L})$ solution was added to the mixture. After $60 \mathrm{~min}$ at $25^{\circ} \mathrm{C}$, absorbance was measured at $765 \mathrm{~nm}$. The results were expressed as gallic acid equivalents in $\mathrm{mg} \cdot \mathrm{mL}^{-1}$.

\section{Determination of phenolics composition with HPLC Analysis}

Samples were prepared as follows: $400 \mathrm{~mL}$ of methanolic extracts containing phenolics were filled up until a final volume of $2 \mathrm{~mL}$ with a stabilizer solution (5 $\%$ of EDTA solution, $5 \%$ of ascorbic acid and $10 \%$ of acetonitrile) and filtered. The chromatography was performed using a Dionex Summit P680A HPLC system with an ASI-100 auto sampler and a PDA-100 photodiode array detector. The separation was performed on a $2 \times 10 \mathrm{~mm}, 5 \mu \mathrm{m} \mathrm{C} 16$ silica columns (DIONEX) with an injection volume of $40 \mu \mathrm{L}$ and a temperature of the column oven $35{ }^{\circ} \mathrm{C}$. The eluent flow rate used was $0.4 \mathrm{~mL} / \mathrm{min}$. A $45 \mathrm{~min}$ gradient program was used eluent A and eluent B with a gradient elution of $100 \%$ of $\mathrm{A}$ mobile phase for $10 \mathrm{~min}$, and isocratic elution of $68 \%$ and $32 \%$ of $\mathrm{A}$ and $\mathrm{B}$ eluents respectively for $35 \mathrm{~min}$. Eluent A containing $90 \mathrm{~mL}$ of acetonitrile, 20 $\mathrm{mL}$ acetic acid and $2 \mathrm{~mL}$ of EDTA solution filled up until $1 \mathrm{~L}$, and eluent $\mathrm{B}$ containing $800 \mathrm{~mL}$ of acetonitrile, $20 \mathrm{~mL}$ of acetic acid and $2 \mathrm{~mL}$ of EDTA solution filled up until $1 \mathrm{~L}$. Peaks were monitored at 254,278 , and $330 \mathrm{~nm}$. The identified phenolics quantity was calculated from HPLC peak area at $278 \mathrm{~nm}$. The (+)-catechin, (-)-epicatechin, $p$-coumeric acid, chlorogenic acid, quercetin dihydrate, vanillic acid, gallic acid and caffeine were purchased from SigmaAldrich as standards.

\section{RESULTS AND DISCUSSION}

\section{Antioxidant activities (AOX)}

Most of the literature data describing the biologically active components of Stevia rebaudiana leaves focus on steviol glycosides, describing them as the main source of beneficial properties of stevia. However, in addition to steviol glycosides, the leaves of Stevia rebaudiana contain also a number of other natural ingredients with potentially significant biological activity. The antioxidant potential (AOX) of different leaf extracts of Stevia rebaudiana Bert. was evaluated in the present study. Four complementary test systems; namely DPPH free radical scavenging, total phenolic and phenolics composition were used for this study. The dry samples of Stevia leaves from all countries had high AOX. The AOX of Stevia plants extracts from Paraguay was about $46 \%$, from India near 33\%, from Egypt (34\%) and Greece (39\%). The highest AOX has been identified for Stevia extracts from Spain (57\%) (Fig 1). The high antioxidant capacity was found in $S$. rebaudiana from Payao Province, Thailand (Phansawan and Poungbangpho, 2007). Shukla et al. (2012) has been found that DPPH activity of aqueous leaf extract $(20,40,50,100$ and $200 \mu \mathrm{g} / \mathrm{ml})$ was increased in a dose dependent manner, which was found in the range of $40.00-72.37 \%$ as compared to ascorbic acid $64.26-82.58 \%$.

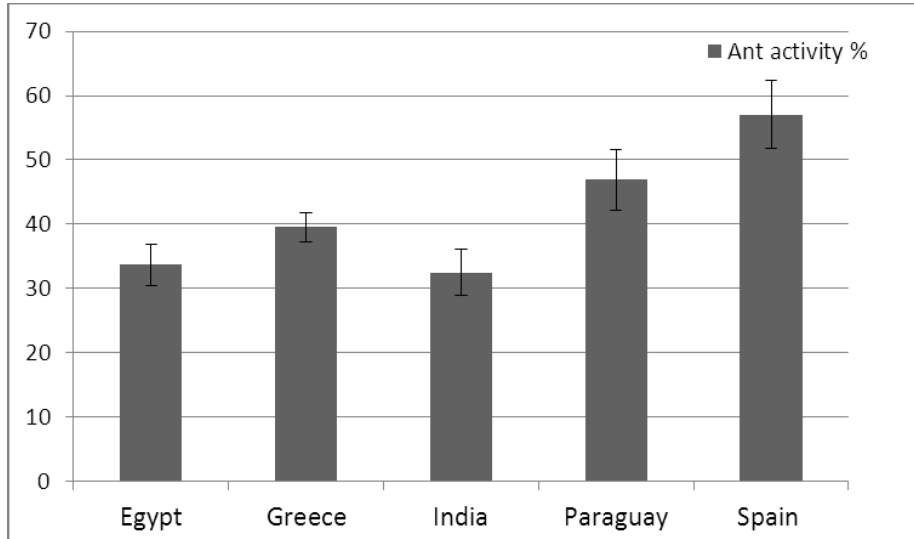

Figure 1 Antioxidant activities of the dry leaves of Stevia rebaudiana of different origin

Moreover, the interaction effect between solvents and antioxidant capacity of extracts showed that the highest antioxidant capacity was found in S. rebaudiana extracted with acetone $(2,96 \mu \mathrm{mol}$ of Trolox $/ \mathrm{mg}$ of crude extraction) and methanol $(2,85 \mu \mathrm{mol}$ of Trolox $/ \mathrm{mg}$ of crude extraction), followed by $S$ rebaudiana extracted with ethanol $(2,64 \mu \mathrm{mol}$ of Trolox $/ \mathrm{mg}$ of crude extraction). It was indicated that these solvents had no effect on potentiating or attenuating the antioxidant capacity of investigated plants (Phansawan, and Poungbangpho, 2007).

The antioxidant activity of plants is most often due to the high content of phenolic acids (gallic, protocatechuic, caffeic, and rosmarinic acids), phenolic diterpenes (carnosol, carnosic acid, rosmanol, and rosmadial), flavonoids (quercetin, catechin, naringenin, and kaempferol), and volatile oils (eugenol, carvacrol, thymol, and menthol) (Brewer, 2011). The high antioxidant activity of $S$. rebaudiana methanol extract also could depend on flavonoid composition there (Ghanta et al.,2007). The analysis of flavonoids in metanolic extracts has shown the presence of six flavonoids there. In addition, another flavone (apigenin) was also isolated and characterized. Also the other authors showed the relationship between AOX and different phenolic compounds as flavonoids and phenolic acids (Rice-Evans et al.,1996). Free radical scavenging ability of phenols depend on the presence of hydroxyl (-OH) and methoxy (-OCH3) groups in their molecules (Cai et al.,2006).

\section{Total phenolics content}

The total phenolic content of the plant materials investigated in this study varied from 5.76 and $15,05 \mathrm{mg}$. $\mathrm{mL}^{-1}$ (Fig. 2).

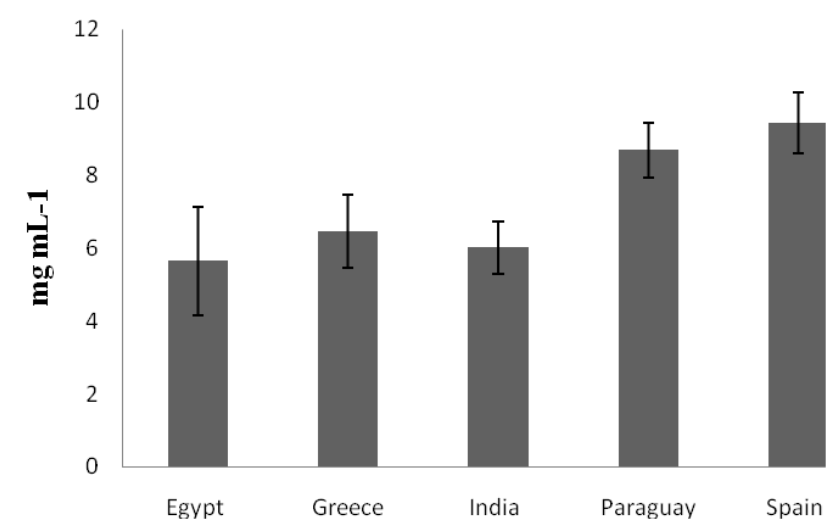

Figure 2 The total phenolic content of the dry leaves of Stevia rebaudiana with different origin. 
Among research materials, moderate levels were found in Stevia leaf samples from Egypt, India and Greece (from 5.64 to $6,01 \mathrm{mg} \mathrm{mL}^{-1}$ ). High amounts of total phenolic contained leaves of Stevia plants from Paraquay and Spain (from 8.69 to $\left.9,44 \mathrm{mg} \mathrm{mL}{ }^{-1}\right)$. Presence of polyphenols influenced the acceptability of the sweeteners marginally (Kaushik et al.,2010).

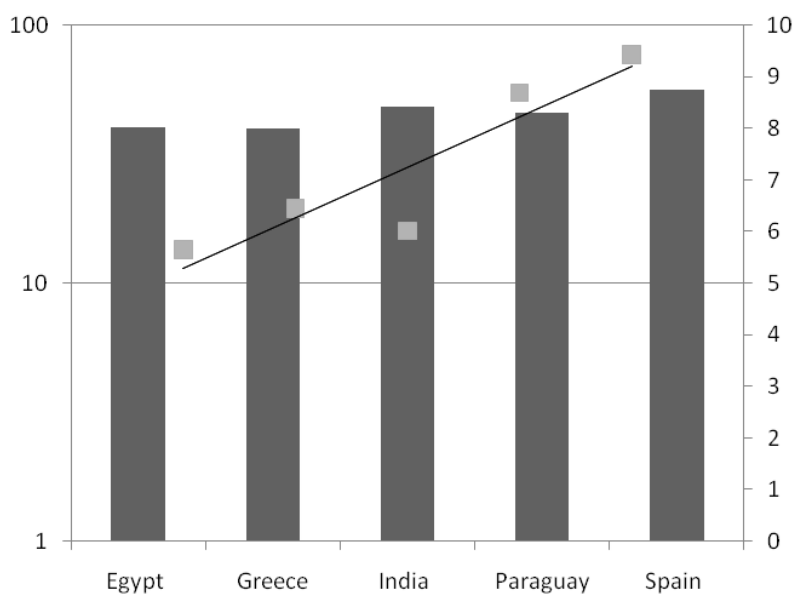

aOX, \% Total Phenolics, mg mL-1 Linear (Total Phenolics, mg mL-1)

Figure 3 Relationship between total phenolic content and antioxidant activity (AOX) of plant materials

The results represented in Fig. 3 indicated the high relationship between total phenolic content and antioxidant activity (AOX) in the Stevia plants from Paraguvay and Spain.

Statistically significant relationships between total phenolics and AOX were also determined in the flaxseed and cereal products (Velioglu et al.,1998). However, the relationship between phenolics and antioxidant activity for the anthocyaninrich materials (cherries, red onion scales and purple potatoes) and for the medicinal plants was not significant (Velioglu et al.,1998) . No significant correlations between the total phenolic content and AOX in berries, fruits, vegetables, cereals, tree materials, plant sprouts has been shown by Velioglu $\boldsymbol{e}$ al.,1998. It is possible to conclude that the antioxidant activity of an extract cannot be predicted on the basis of total phenolic content. It can be explained by the fact that the different phenolic compounds have different responses in the Folin-Ciocalteu method (Kahkonen et al.,1999).

The next step in this research was to study phenolics compositions by HPLC Analysis. The chromatograms of Stevia extracts and chromatogram with standard components are given, respectively, in Figures 4 and 5. Figure 4A shows a satisfactory resolution for all standard components. Examination of the chromatograms of the Stevia leaf extracts obtained at the wavelengths $278 \mathrm{~nm}$ (Figures $4 \mathrm{~B}, 4 \mathrm{C}, 4 \mathrm{D}, 4 \mathrm{E}, 4 \mathrm{~F}$ ) provides some information.
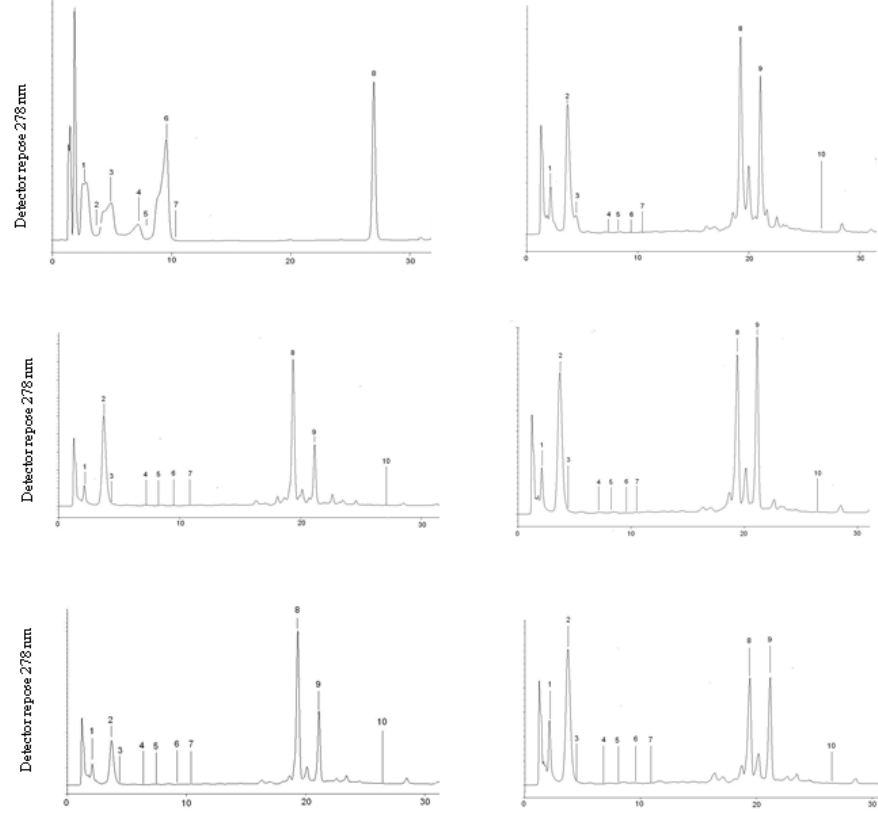

Figure 4 Fractionation of the standard phenolic compounds (A) Peak numbers: (1) caffeic acid RT 2.83; (2) catechin RT 3.83; (3) vanillic acid RT 4.92; (4) epicatechin RT 7.19; (5) gallic acid RT 7.84; (6) p-coumaric acid RT 9.55; (7) ferulic acid RT 10.2; (8) quercetin RT 26.97

Fractionation of the standard phenolic compounds of phenolics extract of Stevia plants from Paraguvay (B), from India (C), from Spain (D), from Egypt (E), from Greece (F) by HPLC at $278 \mathrm{~nm} .80 \mu \mathrm{L}$ Peak numbers: (1) caffeic acid RT 2.1 (2) catechin RT 3.7 (3) vanillic acid RT 4.4 (4) epicatechin RT 7.17 (5) gallic acid RT 7.84 (6) p-coumaric acid RT 9.25 (7) ferulic acid RT 10.70 (8) steviolbioside RT 19.21; (9) RT 21;(10) quercetin RT 26.97

In Stevia leaf extracts from Paraguvay the high content of caffeic acid, catechin and camphoric acid were found. In samples was presented vanilic acid $(3,4 \mu \mathrm{M}$ $\mathrm{mL}^{-1}$ ). There were present the high content of components with RT 19.21 (steviolbioside) and RT 21. In all investigated leaf extracts were presented steviolbioside and RT 21. Regarding data of Major Component Retention Comparison Between HILIC and Reversed-Phase Modes in the Ascentis ${ }^{\circledR}$ Express HPLC Resource Guid RT 19.21 can be identified as steviolbioside (Crafts et al.,2010). In Stevia leaf extract from India the caffeic acid, catechin and camphoric acid were found too (Fig. 4 C).

In Stevia leaf extract from Spain (Fig. 4D) the high content of caffeic acid (22,1 $\left.\mu \mathrm{M} \mathrm{mL}^{-1}\right)$, catechin $\left(64,2 \mu \mathrm{M} \mathrm{mL}^{-1}\right)$ were found. There were present the high content of components with RT 19.21 and RT 21. The content of all these compounds was higher than in other investigated leaf extracts (leaf extract from Paraguay also included).

The same compounds were identified in the leaf extract of Stevia from Egypt (Figure 4E). But their quantity has been less in twice compared to leaf extract from Paraguay. The content of total phenolics in the variant with Stevia leaf extract from Paraguvay was higher 35\% as compared to content of total phenolics in variant with Stevia leaf extract from Egypt. After HPLC analysis possible to see in these variants, the correlation between content of total phenolics and contents of various phenolics compounds in their composition.

\begin{tabular}{lccccc}
\multicolumn{6}{l}{ Table 2 Concentration of the identified phenols in Stevia plants with different origin $\left(\mu \mathrm{M} \mathrm{mL}^{-1}\right.$ of sample extract $)$} \\
$\begin{array}{l}\text { Phenolic } \\
\text { compounds }\end{array}$ & Paraguay & India & Spain & Greece & Egypt \\
\hline Caffeic acid & $16,2 \pm 0,1$ & $13,7 \pm 0,1$ & $22,1 \pm 1,0$ & $29,9 \pm 0,6$ & $10,1 \pm 0,2$ \\
\hline Catechin & $48,1 \pm 1,0$ & $50,9 \pm 2,4$ & $64,2 \pm 2,9$ & $52,9 \pm 2,0$ & $21,3 \pm 1,1$ \\
\hline Vanillic acid & $3,4 \pm 0,1$ & - & - & - & - \\
\hline Epicatechin & $0,7 \pm 0,1$ & $0,8 \pm 0,0$ & $0,9 \pm 0,0$ & $0,6 \pm 0,0$ & $0,2 \pm 0,0$ \\
\hline Gallic acid & $3,8 \pm 0,0$ & $3,2 \pm 0,0$ & $4,5 \pm 0,0$ & $5,9 \pm 0,0$ & $3,06 \pm 0,0$ \\
\hline$p$-coumaric acid & $37,8 \pm 1,4$ & $25,6 \pm 0,9$ & $22,9 \pm 1,0$ & $90,1 \pm 4,2$ & $28,2 \pm 0,8$ \\
\hline Quercetin & $123,6 \pm 5,6$ & $124,1 \pm 6,5$ & $123,7 \pm 5,5$ & $123,6 \pm 1,6$ & $123,7 \pm 2,4$ \\
\hline Total $\left(\mathrm{mg} \mathrm{mL}^{-1}\right)$ & $5,64 \pm 1,49$ & $6,01 \pm 0,71$ & $9,44 \pm 0,83$ & $6,45 \pm 1,0$ & $5,64 \pm 1,49$ \\
\hline
\end{tabular}

The high content of caffeic acid and catechin were found in variant of Stevia leaf extract from Greece and Spain. The contents of caffeic acid were 2 fold higher in Stevia leaves from Greece as from Paraguay and catechin in leaves from Spain 3 fold higher as from Egypt. At the same time the contents of steviolbioside and compound with RT 21 were less in twice as compared to variant with Stevia leaf extract from Paraguay. The leaf extracts from Paraguay had more on phenolic compounds $\left(8,69 \mathrm{mg} \mathrm{mL}^{-1}\right)$ as compared to the samples from India, Greece and Egypt. In the leaf extracts from Paraguay was presented vanillic acid $(3,4 \mu \mathrm{M}$ $\mathrm{mL}^{-1}$ ), and in other experimental plants vanilic acid was absent.

It can evidence about various redistribution quantity of individual phenolics compounds in the leaves of Stevia plants, grown under the different conditions. 


\section{CONCLUSIONS}

Among research materials moderate levels of total phenolics (from 5.64 to 6.45 $\mathrm{mg} \mathrm{mL}^{-1}$ ) were found in Stevia leaf extracts from Egypt, India and Greece that can depend from climate conditions during growing season of Stevia plants. High amounts of total phenolics contained leaves of Stevia plants from Paraguay and Spain (from 8.69 to $9.44 \mathrm{mg} \mathrm{mL}^{-1}$ ), while from Egypt, India and Greece. The dry samples of Stevia plants from all countries had high AOX. The AOX in Stevia plants from Paraguay was about $46 \%$ and from Spain about $57 \%$. Some phenolic compounds were presented not in all samples of Stevia, only the leaves of plants from Paraguay contained vanillic acid. Stevia leaf extracts from Greece, Spain and Paraguay has been shown the high contents of caffeic acid $(29.9,22.1$ and 16.2 $\mu \mathrm{M} \mathrm{mL} \mathrm{mL}^{-1}$ respectively) and catechin $\left(52.9,64.2\right.$ and $48.1 \mu \mathrm{M} \mathrm{mL}^{-1}$ ) as compared to samples from Egypt and India. In these variants were present the high content of components steviolbioside and RT 21 too. In leaf extract from Greece quantity of steviolbioside was less on $50 \%$ as compared to variants of leaf extracts from India and Spain.

\section{REFERENCES}

AL-SAIKHAN, M. S.; HOWARD, L. R.; MILLER, J. C., JR. 1995. Antioxidant activity and total phenolics in different genotypes of potato (Solanum tuberosum, L.). J. Food Sci. 60 (2), 341-343. http://dx.doi.org/10.1111/j.13652621.1995.tb05668.x

BREWER M.S. 2011. Natural antioxidants: Sources, compounds, mechanisms of action, and potential applications. Comp. Rev. Food Sci. Food Saf. 10, 221-247. http://dx.doi.org/10.1111/j.1541-4337.2011.00156.x

CAI Y.Z.; SUN M.; XING J.; LUO Q., CORKE H. 2006. Structure-radical scavenging activity relationships of phenolic compounds from traditional Chinese $\begin{array}{lllll}\text { medicinal plants. } & \text { Life } & \text { Sci. } & 78, & \text { 2872-2888 }\end{array}$ http://dx.doi.org/10.1016/j.lfs.2005.11.004

CHAUDIERE J., FERRARI-ILIOU R. 1999. Intracellular antioxidants: from chemical to biochemical mechanisms. Food Chem. Tox. 37, 949 http://dx.doi.org/10.1016/s0278-6915(99)00090-3

CRAFTS C., BAILEY B., ACWORTH I., PLANTE M., GAMACHE P., WARASKA J. 2010. Sensitive Analysis of Commonly Used Artificial and Natural Sweeteners Including Stevia and Their Impurities and Degradation Products//ESA - A Dionex Company, Chelmsford, MA, USA

GHANTA S., BANERJEE A., PODDAR A., CHATTOPADHYAY S. 2007 Oxidative DNA Damage preventive activity and antioxidant potential of Stevia rebaudiana (Bertoni) Bertoni, a natural sweetener J. Agric. Food Chem. 55, 10962-10967. http://dx.doi.org/10.1021/jf071892q

KAHKONEN M., HOPIA A., HEIKKI J.VUORELA RAUHA, J-P., KALEVI PIHLAJA, KUJALA T. S., HEINONEN M. 1999. Antioxidant activity of plant extracts containing phenolic compounds. J.Agric.Food.Chem. 47, 3954-3963. http://dx.doi.org/10.1021/jf9901461

KAUSHIK R., PRADEEP N., VAMSHI V., GEETHA M., USHA A. 2010 Nutrient composition of cultivated stevia leaves and the infl uence of polyphenols and plant pigments on sensory and antioxidant properties of leaf extracts. J Food Sci Technol (January-February 2010) 47(1), 27-33. http://dx.doi.org/10.1007/s13197-010-0011-7

PRAKASH I, MARKOSYAN A, BUNDERS C. 2014. Development of Next Generation Stevia Sweetener: Rebaudioside M. Foods 3: 162-175; http://dx.doi.org/10.3390/foods3010162

GOYAL SK, SAMSHER, GOYAL RK. 2010. Stevia (Stevia rebaudiana) a biosweetener: a review. Int J Food Sci Nutr. 61(1):110. http://dx.doi.org/10.3109/09637480903193049

MOHDALY A., SARHAN M.A., MAHMOUD A., MOHAMED F.R., SMETANSKA I. 2010. Antioxidant efficacy of potato peels and sugar beet pulp extracts in vegetable oils protection. Food Chemistry 123, 1019-1026. http://dx.doi.org/10.1016/j.foodchem.2010.05.054

KEDARE SB, SINGH RP. 2011. Genesis and development of DPPH method of antioxidant assay. J Food Sci Technol. 48(4), 412-42. http://dx.doi.org/10.1007/s13197-011-0251-1

MISHRA A.N., BHADAURIA S., MULAYAM S., PASRICHA G.R., KUSHWAH B.S. 2010. Synthesis of gold nanoparticles by leaves of zero-calorie sweetener herb (Stevia rebaudiana) and their nanoscopic characterization by spectroscopy and microscopy. International Journal of Green Nanotechnology: $\begin{array}{llll}\text { Physics and Chemistry 118-124 } & \end{array}$ http://dx.doi.org/10.1080/19430871003684705

PHANSAWAN B., POUNGBANGPHO S. 2007. Antioxidant Capacities of Pueraria mirifica, Stevia rebaudiana Bertoni, Curcuma longa Linn., Andrographis paniculata (Burm.f.) Nees. and Cassia alata Linn. for the Development of Dietary Supplement Kasetsart J. Nat. Sci. 41, 548 - 554.

RICE-EVANS C.A., MILLER N.J., BOLWELL P.G., BRAMLEY P.M., PRIDHAM J.B. 1995. The relative antioxidant activities of plant-de-rived polyphenolic flavonoids. Free Radical Research 22, 375-383. http://dx.doi.org/10.3109/10715769509145649
RICE-EVANS C.A., MILLER N.J., PAGANDA G. 1996. Structure-antioxidant activity relationships of flavonoids and phenolic acids. Free Radical Biology \& Medicine 20 (7), 933-956. http://dx.doi.org/10.1016/0891-5849(95)02227-9

SHUKLA S., MEHTA A., BAJPAI V.K., SHUKLA S. 2009. In vitro antioxidant activity and total phenolic content of ethanolic leaf extract of Stevia rebaudiana Bert. Food and chemical toxicology an international journal published for the British Industrial Biological Research Association 47 (9), 2338-2343. http://dx.doi.org/10.1016/j.fct.2009.06.024

SHUKLA S. MEHTA A., MEHTA P., BAJPAI V.K. 2012. Antioxidant ability and total phenolic content of aqueous leaf extract of Stevia rebaudiana Bert. Experimental and Toxicologic Pathology 64 (7-8), 807-811. http://dx.doi.org/10.1016/i.etp.2011.02.002

SINGLETON V.L., ROSSI, J.A. 1965. Colorimetry of total phenolics with phosphomolybdic-phosphotungstic acid reagents. Am.J. Enol. Vitic. 16, 144-58.

VELIOGLU Y. S., MAZZA G., GAO L., OOMAH B. D. 1998. Antioxidan activity and total phenolics in selected fruits, vegetables, and grain products. $J$. Agric. Food Chem. 46, 4113-4117. http://dx.doi.org/10.1021/jf9801973 ZHANG D., HAMAUZU Y. 2004. Phenolic compounds and their antioxidan properties in different tissues of carrots (Daucus carota L.) Food, Agriculture \& Environment (JFAE). 2 (1), 95-100. 